\title{
How the Intercropping between Corn and Palisade Grass Cultivars Affects Forage Production and Pastures Characteristics under Grazing
}

\author{
Estella Rosseto Janusckiewicz1 ${ }^{1}$, Carina Bellentani Chiarelli², Duarte Castro Cunha Neto², \\ Elisamara Raposo ${ }^{1}$, Ana Cláudia Ruggieri ${ }^{1}$ \\ ${ }^{1}$ Department of Animal Science, University of Sao Paulo, FCAV/UNESP, Sao Paulo, Brazil \\ ${ }^{2}$ University of Sao Paulo, FCAV/UNESP, Sao Paulo, Brazil \\ Email: estella rosseto_janusckiewicz@yahoo.com.br, acruggieri@fcav.unesp.br
}

Received 25 May 2015; accepted 20 June 2015; published 23 June 2015

Copyright (C) 2015 by authors and Scientific Research Publishing Inc.

This work is licensed under the Creative Commons Attribution International License (CC BY).

http://creativecommons.org/licenses/by/4.0/

(c) (;) Dpen Access

\section{Abstract}

Crop-livestock integrated systems have been identified as an excellent option to use land efficiently. This study investigates how the intercropping between corn and three palisade grass cultivars affects the species productivity and the physiological and structural characteristics of swards grazed under $95 \%$ light interception under mob stocking. Evaluations were performed before corn harvest and during three grazing cycles. Similarity between the cultivars on the proportion of corn morphological components has shown that none of the studied forage plants had influence on the growth of corn. The crop-livestock integrated system with corn modified the proportion of palisade grass cultivars' morphological components, promoting the development of Xaraes cultivar. In the pre-grazing in the grazing cycles, considering $95 \%$ of light interception the Xaraes cultivar showed higher height $(0.47 \mathrm{~m})$ compared with Marandu $(0.37 \mathrm{~m})$ and similar to Piata $(0.42 \mathrm{~m})$. Forage density was higher in the second grazing cycle only when the forage mass was also greater with greater contribution of both leaves and stems compared to the other cycles. Mass of leaves, stems and dead material was similar between the cultivars both pre- and postgrazing. The corn and forage intercropping did not affect the growth and development of palisade grass pastures and it is a viable alternative for the crop-livestock integrated system. Corn production is not affected by the palisade grass cultivars but production can be affected by environmental conditions mainly rainfall. The Marandu, Xaraes and Piata cultivars can be recommended for integration farming system in crop-livestock integrated system and are recommended for sward managed under $95 \%$ light interception and $15 \mathrm{~cm}$ high residue. 


\section{Keywords}

\section{Crop-Livestock Integrated System, Marandu, Piata, Xaraes}

\section{Introduction}

The efficient use of natural resources requires intensifying land use, which is a good alternative to minimize the environmental stress brought by the opening of new areas for agricultural production. This model however must be guided by the efficient use of physical resources comprising recovering of disturbed and degraded areas by use of input-saving technologies [1].

A crop-livestock integrated system (CLIS) is a model production that succeeds, at the same area, pastures to animal production and vegetal crops [2]. The CLIS has the recovery of degradation pasture as the first benefit. It is supported by the fact that in Brazil we currently have 174 million hectares of cultivated pastures, and $60 \%$ of those are degraded or in the degradation process [3]. Thus, CLIS has drawn attention due to its advantages compared to only agriculture or livestock farming systems. Among them the possibility of efficient land use and culture diversification within the same environment can benefit them both. According to [2], to make this system successful, some presuppositions must be considered such as crop rotation and adequate pasture management. CLIS has been cultivated with many crops such as: soybeans, corn, pearl millet, sorghum, cotton, sunflower, etc. and especially perennial tropical grasses as Brachiaria spp., intercropped or not [4].

Tropical forage Marandu palisade grass has been widely used in CLIS giving the large grazing area occupied by it in Brazil. [5] concluded that corn, sorghum, millet and rice can be intercropped with Marandu grass to recover degraded grazing areas. The authors stated that the presence of cereals resulted in higher tiller number, leaf area index, leaves and stems dry weight and Marandu growth rate up to grain harvest. However, after the grain harvest, the number of tillers of Marandu was higher than the forage only and 60 - 70 days after cereal harvesting, forage availability was similar to forage only.

When there is no problem with water and nutrient availability, the use of corn and Marandu palisade grass intercropping under row spacing conditions of 0.45 and $0.90 \mathrm{~m}$ provides an option for the production of forage dry matter without reducing the corn grain yield [6]. However, [7] highlighted some problems related with Marandu grass intercropping, which could make its cultivation unfeasible, such as seasonality, low efficiency of crop control with glyphosate herbicide, and the cultivar slowness to enter senescence. The latter implies that the ideal conditions for planting succession crops are met only from 21 to 28 days after herbicide application, contributing to late sowing. Thus, studying other palisade grass cultivars intercropped with corn becomes important for the viability of the system.

On the other hand, it is also necessary to study grazed pastures implanted from CLIS since most of the researches are made with cut and instead of grazing. Considering this fact and the importance of the study that other Brachiaria cultivars give better opportunity for animal production, the present study investigates how the intercropping between corn and three palisade grass cultivars affects species productivity and the physiological and structural characteristics of swards grazed under 95\% light interception in intermittent stocking.

\section{Methods and Materials}

The study was conducted in an experimental area of $1,485 \mathrm{~m}^{2}$ at Sao Paulo State University (FCAV/UNESP), Sao Paulo State, Brazil, $21^{\circ} 14^{\prime} 05^{\prime \prime} \mathrm{S}, 4^{\circ} 17^{\prime} 09^{\prime \prime} \mathrm{W}$, at 615 meters above sea level. The climate was classified according to Köppen, as megathermal tropical climate of savanna with dry winter and hot and rainy summer (Aw). Soils were classified as clayey Oxisol [8] and the chemical characteristics of the soil at $0-20 \mathrm{~cm}$ before planting are presented in Table 1.

Table 1. Chemical characteristics of the clayey oxisol under integrated crop-livestock systems during sowing of palisade grass cultivars intercropped with corn.

\begin{tabular}{cccccccccc}
\hline $\mathrm{Ca}^{2+}$ & $\mathrm{Mg}$ & $\mathrm{K}$ & $\mathrm{H}+\mathrm{Al}$ & $\mathrm{P}$ & $\mathrm{SB}^{(1)}$ & $\mathrm{V}^{(2)}$ & $\mathrm{OM}^{(3)}$ & $\mathrm{pH}$ \\
\hline \multicolumn{4}{c}{$\mathrm{mmol}_{\mathrm{c}} \cdot \mathrm{dm}^{-3}$} & & $\mathrm{mg} \cdot \mathrm{dm}^{-3}$ & & $\%$ & $\mathrm{~g} \cdot \mathrm{dm}^{-3}$ & $\mathrm{CaCl}_{2}$ \\
& 12 & 4.9 & 47 & 15 & 58.9 & 56 & 33 & 5.0 \\
\hline
\end{tabular}

${ }^{(1)} \mathrm{SB}$ : base sum; ${ }^{(2)} \mathrm{V}$ : base saturation; ${ }^{(3)} \mathrm{OM}$ : organic matter. 
A mixture of the systemic herbicides glyphosate + 2.4-D was applied to the area eight days before sowing. Twenty three $\mathrm{kg} \cdot \mathrm{ha}^{-1}$ of corn and $15 \mathrm{~kg} \cdot \mathrm{ha}^{-1}$ of palisade grass seeds were sown in direct system on February $28^{\text {th }}$, 2009. Corn seeds were treated with non-systemic preventive fungicidal Phthalimide, using $0.75 \mathrm{~g} \cdot \mathrm{kg}^{-1}$ of seeds. Palisade grass seeds were mixed with simple superphosphate fertilizer $\left(500 \mathrm{~kg} \cdot \mathrm{ha}^{-1}\right)$ and seeded between rows of corn at 8 inches deep with $0.45 \mathrm{~m}$ spacing. The topdressing of the experimental area consisted of applying 100 $\mathrm{kg}$ of the 20.4.20 formula over the entire area, 34 days after sowing, which corresponds to developmental stage $\mathrm{V}_{5}$. The experiment consisted of a randomized complete block experimental design, with five replications. Treatments were comprised of the forages: Brachiaria brizantha cv. Marandu, Brachiaria brizantha cv. Xaraes and Brachiaria brizantha cv. Piata, intercropped in over-sowing corn for implantation of integrated crop-livestock system. The variety of corn used in this study was CATI AL-34. Corn for silage was harvested mechanically at 103 days after sowing, on June $06^{\text {th }}$, 2009. This cultivars are chosen based on the fact that Marandu grass is the most used cultivar and Xaraes and Piata are newest cultivars of Brachiaria brizantha until the moment of this experiment.

Three random samples of corn per plot were cut at ground level using a $1 \mathrm{~m}^{2}$ square. We weighted the samples and selected three representative plants that were subsequently separated into leaves, stems, ear and straw. The fractions were dried at $55^{\circ} \mathrm{C}$, for 72 hours. Dry mass percentage was calculated for each fraction to obtain dry yield. A cm graduated ruler was used to measure the plant and ear insertion heights of 20 plants per plot in the central rows. Before corn harvest three random samples of palisade grass cultivars per plot were cut close to the ground using a $0.25 \mathrm{~m}^{2}$ square. The samples were weighed and separated into sub-samples to calculate total dry mass, morphological components (leaves, stems and dead material) by drying samples at $55^{\circ} \mathrm{C}$, for 72 hours and the leaf area for calculating LAI $\left(\mathrm{m}^{2} \cdot \mathrm{m}^{2}\right)$ using a LICOR LI-3000.

To evaluate the development of palisade grass pastures after corn harvest were conducted topdressing of 50 $\mathrm{kg} \cdot \mathrm{ha}^{-1}$ nitrogen on December $24^{\text {th }}$, 2009 and repeated after each grazing cycle. The evaluation periods of dry matter production and structural characteristics of forages were conducted during the rainy season at three grazing cycles with mob stocking [9] on January $12^{\text {th }}, 2010$ ( $1^{\text {st }}$ grazing cycle), February $11^{\text {th }}, 2010$ ( $2^{\text {nd }}$ grazing cycle $)$ and March $11^{\text {th }}, 2010$ ( $3^{\text {rd }}$ grazing cycle). Female, non-lactating Holstein cows weighing on average $400 \mathrm{~kg}$ grazed the experimental pastures when reached $95 \%$ light interception and ending when reached a residue of 15 $\mathrm{cm}$ in height of plants. Values of light interception and LAI were estimated using the canopy analyzer-AccuPAR Model L-80 PAR/LAI (Decagon ${ }^{\circledR}$ devices). LAI was calculated based on collected data, leaf area $\left(\mathrm{dm}^{2}\right)$, dry weight of the samples intended to determine the leaf area and leaf dry matter production in $0.25 \mathrm{~m}^{2}$.

Before each grazing, height was measured in ten points inside the plots using the cm-graded ruler to calculate average height for sampling. Subsequently, two samples were cut at soil level from an area defined by the 0.25 $\mathrm{m}^{2}$ frames inside each plot and, then, taken to the laboratory, weighed and separated into leaves, stems and dead material, and dried at $55^{\circ} \mathrm{C}$ for 72 hours to determine the percentage of forage mass. Density $\left(\mathrm{kg} \cdot \mathrm{DM} \cdot \mathrm{ha}^{-1} \cdot \mathrm{cm}^{-1}\right.$ ) is given by dividing mass by height.

Throughout the experimental period from sowing until the last grazing cycle the rainfall and temperature data were monitored (Figure 1).

The experiment was conducted as a randomized complete block experimental design, with five replications. Treatments were three Brachiaria brizantha cultivars intercropped in over-sowing corn for implantation of

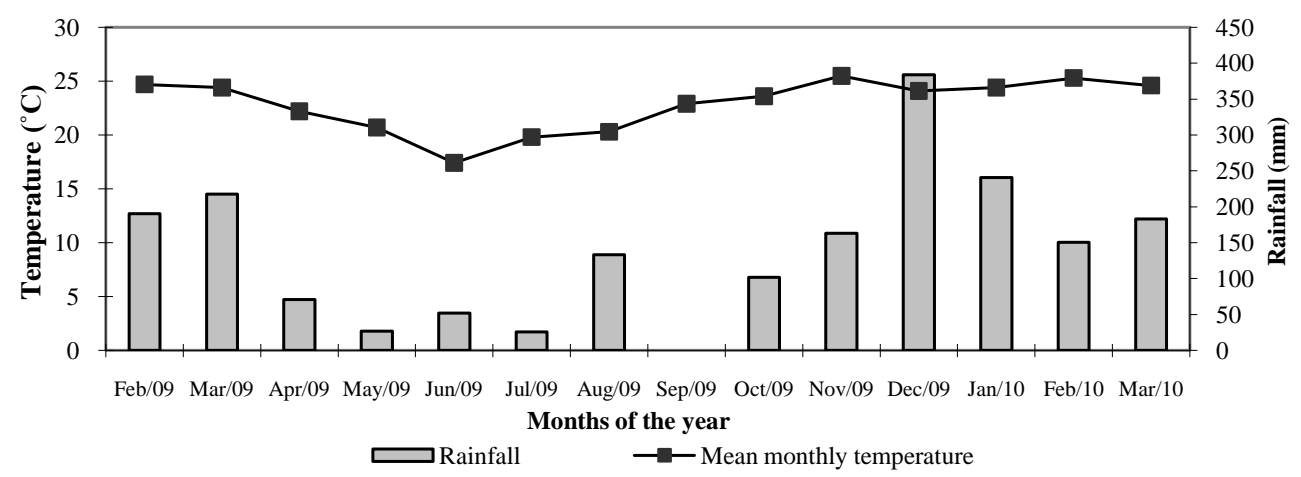

Figure 1. Rainfall $(\mathrm{mm})$ and monthly temperature $\left({ }^{\circ} \mathrm{C}\right)$ during the experimental period: establishment of integration between corn and Brachiaria cultivars (February to June 2009), establishment of pastures (July to December 2009) and three grazing cycles (January to March 2010). 
CLIS. Data were subjected to analysis of variance and means were compared by Tukey’s test, with significance level of $5 \%$ probability using the software SAS [10].

\section{Results and Discussion}

No significant effects ( $\mathrm{P}>0.05$ ) were detected for corn yield (green and dry matter), plant and ear insertion heights and the percentage of husked ears between treatments (Table 2). These results demonstrate that palisade grass cultivars did not affect the corn development, and probably there was no competition between species studied. Corn average green and dry yield were of $18,217 \mathrm{~kg} \cdot \mathrm{ha}^{-1}$ and $5,987 \mathrm{~kg} \cdot \mathrm{ha}^{-1}$, respectively. The lower yield observed in corn when compared with other studies [11] [12] is possibly due to the time the corn was planted (off-season) and not by competition between plants. The studies above mentioned the authors also found no differences in corn yield when planted in monoculture or in consortium with forage plants. On the other hand [13] observed lower and similar productivity to those observed in our study when the corn was grown in off-season period. However, it is verified that there is no studies of CLIS on literature with corn for silage with focus on plant yield of corn.

The mean values of plant and ear insertion heights ( $2.24 \mathrm{~m}$ and $1.28 \mathrm{~m}$, respectively) were slightly lower than the values of $2.35 \mathrm{~m}$ and $1.36 \mathrm{~m}$, and $2.49 \mathrm{~m}$ and $1.27 \mathrm{~m}$ respectively, obtained by [14] and [15] for corn plantation used to produce silage in a similar region and climate. However, our results are higher than reported by [6] with values of $1.54 \mathrm{~m}$ and $0.55 \mathrm{~m}$, respectively. For the husked ears [14] found $38.41 \%$, contrasting with $26.58 \%$ observed in this study. In general, characteristics of plant and ear insertion heights, dry and green yield, and percentage of husked ears in corn plants (Table 2) showed lower values than those observed in the studies cited, but all of researches cited were conducted on season. Studies conducted of season normally report less performance of cultures. As example, [16] observed values of plant and ear insertion heights (1.51 m and $0.75 \mathrm{~m}$ ). Our study was conducted in a period when the rainfall was decreasing month to month (Figure 1).

Despite the palisade grass morphological components were different in the integration with corn, other characteristics were similar. Thus, dry mass, leaf area index (LAI) and tillers number of palisade grass cultivars were not $(\mathrm{P}>0.05)$ significantly different between treatments with average values of $5,719 \mathrm{~kg} \cdot \mathrm{ha}^{-1}, 3.98$ and 126.49 tillers $\cdot \mathrm{m}^{-2}$. LAI obtained is consistent with found by other authors [17] [18] for different cultivars of palisade grass in monoculture demonstrating that intercropping with corn did not impair light interception by the sward. LAI and number of tillers for Piata palisade grass are similar to observed by [15] in corn and Piata palisade grass planted in CLIS.

The morphological components of corn were not significantly different $(\mathrm{P}>0.05)$ between treatments with average values of $17.54 \%, 35.19 \%, 33.77 \%$, and $13.49 \%$ to leaves, stems, ears and straw. Similarity between the cultivars on the proportion of corn morphological components has shown that none of the studied forage plants had influence on the growth of corn. The CLIS with corn modified the proportion of palisade grass cultivars morphological components (Table 3), promoting the development of Xaraes cultivar which demonstrated highest

Table 2. Height of plant and ear insertion (HEI), green and dry masses and percentage of husked ears in the green mass before corn harvest.

\begin{tabular}{cccccc}
\hline Cultivars & $\begin{array}{c}\text { Plant height } \\
(\mathrm{m})\end{array}$ & $\begin{array}{c}\text { HEI } \\
(\mathrm{m})\end{array}$ & $\begin{array}{c}\text { Green } \\
\text { yield }\left(\mathrm{Kg}^{-1} \mathrm{ha}^{-1}\right)\end{array}$ & $\begin{array}{c}\text { Dry } \\
\text { yield }\left(\mathrm{Kg}_{\mathrm{ha}}{ }^{-1}\right)\end{array}$ & $\begin{array}{c}\text { Husked } \\
\text { ear }(\%)\end{array}$ \\
\hline Piata & 2.22 & 1.28 & 18,407 & 6,027 & 27.77 \\
Marandu & 2.32 & 1.32 & 17,675 & 5,829 & 26.10 \\
Xaraes & 2.20 & 1.24 & 18,568 & 6,104 & 25.88 \\
\hline
\end{tabular}

Means followed by different lower cases in the column (cultivars) are significantly different by Tukey’s test $(\mathrm{P}<0.05)$.

Table 3. Percentage of different morphological components and leaf:stem ratio of palisade grass cultivars before corn harvest.

\begin{tabular}{ccccc}
\hline Cultivars & Leaves (\%) & Stems (\%) & Leaf: stem ratio & Dead material (\%) \\
\hline Piata & $38.08 \mathrm{~b}$ & $54.82 \mathrm{a}$ & $0.69 \mathrm{~b}$ & $0.10 \mathrm{~b}$ \\
Marandu & $38.52 \mathrm{~b}$ & $48.83 \mathrm{~b}$ & $0.79 \mathrm{~b}$ & $12.63 \mathrm{a}$ \\
Xaraes & $45.02 \mathrm{a}$ & $44.13 \mathrm{c}$ & $1.02 \mathrm{a}$ & $10.84 \mathrm{a}$ \\
\hline
\end{tabular}

Means followed by different lower cases in the column (cultivars) are significantly different by Tukey’s test $(\mathrm{P}<0.05)$. 
( $\mathrm{P}<0.05)$ proportion of leaves $(45.02 \%)$ and the smallest of stems $(44.13 \%)$ compared to the others. These observations suggest that the adaptation of Xaraes cultivar to the CLIS with corn was better, i.e., the shading caused by corn plants did not reduce the light interception by the Xaraes sward that could photosynthesize normally and prioritize the production of leaves and not the stem elongation. In addition during the growing period of plants the precipitation was low (about $50 \mathrm{~mm}$, Figure 1). Different to that observed in this study, [19] comparing different species and palisade grass cultivars in CLIS with corn observed that the cultivar that showed better percentage and crude protein in the leaves in the offseason was the Piata.

A higher $(\mathrm{P}<0.05)$ leaf:stem ratio for Xaraes shows that the other two cultivars probably lengthened the stem to win the competition for light with corn, contributing to greater participation of this component in the forage mass and consequently to lower leaf:stem ratio (Table 3). According to [20] this difference is due to the intrinsic morphological characteristics of each cultivar such as shade tolerance and the strategies developed by the plant to address deficiencies imposed by competition. Others studied characteristics in forage were similar that demonstrates the viability of the association between these two plants.

[15] studied corn and Piata palisade grass planted in CLIS and different grass sowing densities. In the same sowing density at the present study [15] found higher percentages of corn leaves, ears and Piata leaves (21.64\%, $45.02 \%$ and $48.10 \%$, respectively) and smaller percentages of stems for both Piata (35.22\%) as for corn (25.91\%) than those observed by us. These differences are due to the climatic conditions of the experimental years. In our experiment there was a period of few rains during the plants development with an accumulation of $315 \mathrm{~mm}$ which is little when compared to the work of [15] (approximately $440 \mathrm{~mm}$ ). The lower occurrence of rain and consequent reduced availability of water damaged plant growth.

In the pre-grazing in the grazing cycles, considering $95 \%$ of light interception the Xaraes cultivar showed higher $(\mathrm{P}<0.05)$ height $(0.47 \mathrm{~m})$ compared with Marandu $(0.37 \mathrm{~m})$ and similar to Piata $(0.42 \mathrm{~m})$. Height differences observed in the sward are due to the growth habit of different cultivars. Xaraes and Piata have caespitose growth, tending to be higher than Marandu, which has decumbent growth. [21] found similar heights to Xaraes cultivar in different grazing intensities, with values ranging between 0.45 and $0.54 \mathrm{~m}$. [22] in study with pastures under different heights concluded that Piata grass has great management flexibility under continuous stocking and can be managed between 15 and $45 \mathrm{~cm}$.

For the variables LAI and density pre-grazing there was no significant difference $(\mathrm{P}>0.05)$ between palisade grass cultivars with average values of 5.31 and $160.82 \mathrm{~kg} \cdot \mathrm{ha}^{-1} \cdot \mathrm{cm}^{-1}$, respectively. Despite the LAI be similar among cultivars values are consistent with other studies in the literature as [22] that compared three methods for estimating LAI in Marandu cultivar subjected to different grazing heights and they found average values of 4.6, 5.1 and 5.5 for sward heights of $0.2,0.3$ and $0.4 \mathrm{~m}$ respectively.

Under pre-grazing conditions the grazing cycles did not affect $(\mathrm{P}>0.05)$ average sward height in the last two cycles, which was significantly higher in the first cycle $(\mathrm{P}<0.05)$, probably due to the lack of prior defoliation (Table 4). LAI was favored with during the grazing. In study to compare three methods for estimating LAI in Marandu cultivar subjected to different grazing heights [23] found LAI of 5.0 at summer. These authors observed differences in methods to detect seasonal variations in this variable and verified that the LAI measured at LICOR showed differences only between summer and other seasons. In Piata cultivar [24] obtained LAI values of 5.06 and 5.25, respectively in heights of 0.3 and $0.4 \mathrm{~m}$ in March.

Forage density was higher in the second grazing cycle only, when the forage mass was also greater with greater contribution of both leaves and stems compared to the other cycles (Table 4). This is probably due to higher rainfall after the first grazing cycle, which stimulated the growth of grasses for the next cycle (Figure 1). [25] observed that the amount of rain favored the appearance of new leaves, verified by increasing the density of Marandu. The average density found by [24] was $163.5 \mathrm{~kg} \cdot \mathrm{cm}^{-1}$ from January to early April.

Table 4. Height, leaf area index (LAI) and density of palisade grass pastures in pre-grazing.

\begin{tabular}{cccc}
\hline Grazing cycles & Height $(\mathrm{m})$ & LAI & ${\text { Density }\left(\mathrm{kg} \cdot \mathrm{ha}^{-1} \cdot \mathrm{cm}^{-1}\right)}$ \\
\hline $1^{\text {st }}(\mathrm{Jan})$ & $0.48 \mathrm{~A}$ & $5.00 \mathrm{~B}$ & $131.50 \mathrm{~B}$ \\
$2^{\text {nd }}(\mathrm{Feb})$ & $0.39 \mathrm{~B}$ & $4.78 \mathrm{~B}$ & $208.68 \mathrm{~A}$ \\
$3^{\text {rd }}(\mathrm{Mar})$ & $0.39 \mathrm{~B}$ & $6.15 \mathrm{~A}$ & $142.28 \mathrm{~B}$ \\
\hline
\end{tabular}

Means followed by different upper cases (grazing cycles) in the column are significantly different by Tukey’s test $(\mathrm{P}<0.05)$. 
Mass of leaves, stems and dead material was similar $(\mathrm{P}>0.05)$ between the cultivars, both pre- and postgrazing. The averages pre-grazing masses were 3,$079 ; 2,298$ and $1,081 \mathrm{~kg} \cdot \mathrm{ha}^{-1}$ for leaves, stems and dead material, respectively. Under post-grazing conditions the averages masses were 435; 1,485 and 1,375 $\mathrm{kg} \cdot \mathrm{ha}^{-1}$ for leaves, stems and dead material, respectively. The decrease in the amount of leaves between the pre- and post-grazing demonstrates that the three cultivars were well accepted as food for animals. Besides, also there was a decrease in the mass of stems which allow to infer that possibly those with young tissues was consumed. Already the increase of the amount of dead material indicates that occurred shoot accumulation not consumed through the grazing. The no significant differences $(\mathrm{P}>0.05)$ between cultivars for some variables (LAI, density and morphological components masses) denote that the management adopted was appropriate. The corn and forage intercropping did not affect the growth and development of palisade grass pastures, and it is a viable alternative for the CLIS. According to [26] Marandu, Xaraes and Piata cultivars are well adapted to Cerrado soils and are excellent alternatives for diversification of forage.

In the pre-grazing leaves and stems mass were significantly higher $(\mathrm{P}<0.05)$ in the second cycle compared to the others (Table 5). Post-grazing, however leaves mass did not differ $(\mathrm{P}>0.05)$ between grazing cycles, only stems $(\mathrm{P}<0.05)$ with higher mass in the first two cycles. Considering pre- and post-grazing, no differences $(\mathrm{P}>$ 0.05 ) were found on the dead material masses among grazing cycles (Table 5).

The greater amount of leaves and stems (Table 5) in the second cycle $(\mathrm{P}<0.05)$ under pre-grazing possibly resulted as stated earlier from the rainfall in the previous period (312.2 $\mathrm{mm}$ on average). Allied to residual effects of nitrogen fertilization of December have stimulated photosynthesis with a consequent increase in the production of leaves and stems. Furthermore, the lowest value $(\mathrm{P}<0.05)$ of leaves mass of the third cycle suggest that the animal grazing; changing climatic conditions throughout the summer and grasses growth habit, were no longer favorable to rapid plant recovery after grazing. [21] evaluated the structure grazing on Xaraes cultivar under intermittent stocking in two summers and observed variability in the structure of pastures for the years and grazing cycles within each year. [17] found similar masses for Xaraes pastures under post-grazing conditions evaluated in summer with values of 1,410 and $1,490 \mathrm{~kg} \cdot \mathrm{ha}^{-1}$ for stems and dead material, respectively.

Considering that livestock sector uses palisade grass (70\%) as the main source of food for livestock and Marandu cultivar is the predominant source of animal diet (approximately 95\%) of animals slaughtered in Brazil [3], it becomes clear the importance of studies involving these cultivars. Based on the evaluated structural characteristics assessed in our study, the palisade grass cultivars presented similar adaptation to management in CLIS. In the present study was not evaluated the forage quality, but others authors [19] [27] have demonstrated the favorable nutritional quality of these cultivars. [19] observed that Marandu, Xaraes and Piata palisade grass are more appropriate to provide best quality food compared with MG-4 palisade grass, Brachiaria decumbens and Brachiaria ruziziensis when intercropped in oversown corn for implantation of CLIS. Crude protein contents were $12.63 \%, 12.93 \%$ and $13.96 \%$ and in vitro dry matter digestibility were $72.10 \%$, $73.14 \%$ and $74.32 \%$ for Marandu, Xaraes and Piata, respectively. [27] observed that Piata had the best chemical composition compared to the Marandu and Xaraes under different cutting intensities in the course of one year with $11.42 \%, 11.86 \%$ and $12.83 \%$ of crude protein contents and $55.68 \%, 55.28 \%$ and $59.43 \%$ of total digestible nutrient for Marandu, Xaraes and Piata, respectively. These authors also observed that seasonality also influenced the nutritional value of these forages.

Table 5. Dry mass of different morphological components of palisade grass pastures in pre and post-grazing conditions.

\begin{tabular}{|c|c|c|c|}
\hline Grazing cycle & Leaves mass $\left(\mathrm{Kg} \cdot \mathrm{ha}^{-1}\right)$ & Stems mass $\left(\mathrm{Kg} \cdot \mathrm{ha}^{-1}\right)$ & Dead material mass $\left(\mathrm{Kg} \cdot \mathrm{ha}^{-1}\right)$ \\
\hline & \multicolumn{3}{|c|}{ Pre-grazing } \\
\hline $1^{\text {st }}(\mathrm{Jan})$ & $3,177 \mathrm{~B}$ & 2,111 B & 942 \\
\hline $2^{\text {nd }}(F e b)$ & $4,007 \mathrm{~A}$ & 2,889 A & 932 \\
\hline \multirow[t]{2}{*}{$3^{\text {rd }}$ (Mar) } & $2,053 \mathrm{C}$ & $1,893 \mathrm{~B}$ & 1,369 \\
\hline & \multicolumn{3}{|c|}{ Post-grazing } \\
\hline $1^{\text {st }}(\operatorname{Jan})$ & 377 & $1,609 \mathrm{~A}$ & 1,299 \\
\hline $2^{\text {nd }}(F e b)$ & 441 & $1,808 \mathrm{~A}$ & 1,320 \\
\hline $3^{\text {rd }}$ (Mar) & 486 & 1,038 B & 1,506 \\
\hline
\end{tabular}

Means followed by different upper cases (grazing cycles) in the column are significantly different by Tukey's test $(\mathrm{P}<0.05)$. 


\section{Conclusion}

In the CLIS, corn production is not affected by the palisade grass cultivars, but production can be affected by environmental conditions mainly rainfall. The Marandu, Xaraes and Piata cultivars can be recommended for integration farming system, in CLIS. The management was efficient for the three palisade grass (Brachiaria brizantha) cultivars evaluated. Thus, these three cultivars are recommended for sward management under 95\% light interception and $15 \mathrm{~cm}$ high residue in intermittent stocking.

\section{References}

[1] Barcellos, A.O., Ramos, A.K.B., Vilela, L. and Martha Junior, G.B. (2008) Sustentabilidade da produção animal baseada em pastagens consorciadas e no emprego de leguminosas exclusivas, na forma de banco de proteína, nos trópicos brasileiros. Revista Brasileira de Zootecnia, 37, 51-67. http://dx.doi.org/10.1590/S1516-35982008001300008

[2] Balbinot Junior, A.A., Moraes, A., Veiga, M., Pelissari, A. and Dieckow, J. (2009) Crop-Livestock System: Intensified Use of Agricultural Lands. Ciência Rural, 39, 1925-1933. http://dx.doi.org/10.1590/S0103-84782009005000107

[3] Paulino, V.T., Teixeira, E.M.C., Duarte, K.M.R. and Lucena, M.A.C. (2014) Chemical Attributes of a Typic Acrudox Soil on Marandu Palisade Grass under Rotational Stocking, Liming and Nitrogen Fertilisation. American Journal of Plant Sciences, 5, 1039-1048. http://dx.doi.org/10.4236/ajps.2014.57116

[4] Macedo, M.C.M. (2009) Crop and Livestock Integration: The State of the Art and the Near Future. Revista Brasileira de Zootecnia, 38, 133-146. http://dx.doi.org/10.1590/S1516-35982009001300015

[5] Portes, T.A., Carvalho, S.I.C., Oliveira, I.P. and Kluthcouski, J. (2000) Growth Analysis of Brachiaria cultivar Sole and Intercropped Cereals. Pesquisa Agropecuária Brasileira, 35, 1349-1358. http://dx.doi.org/10.1590/S0100-204X2000000700009

[6] Borghi, E., Crusciol, C.A.C., Nascente, A.S., Mateus, G.P., Martins, P.O. and Costa, C. (2013) Effects of Row Spacing and Intercrop on Corn Grain Yield and Forage Production of Palisade Grass. Crop and Pasture Science, 63, 11061113. http://dx.doi.org/10.1071/CP12344

[7] Machado, L.A.Z. and Valle, C.B. (2011) Agronomic Performance of Palisade Grass Genotypes in Succession to Soybean. Pesquisa Agropecuária Brasileira, 46, 1454-1462. http://dx.doi.org/10.1590/S0100-204X2011001100006

[8] USDA-NRCS (2010) Keys to Soil Taxonomy. 11th Edition, Department of Agriculture, Soil Survey Staff, Washington DC, $346 \mathrm{p}$.

[9] Allen, V.G., Batello, C., Berretta, E.J., Hodgson, J., Kothmann, M., Li, X., McIvor, J., Milne, J., Morris, C., Peeters, A. and Sanderson, M. (2011) An International Terminology for Grazing Lands and Grazing Animals. Grass and Forage Scence, 66, 2-28. http://dx.doi.org/10.1111/j.1365-2494.2010.00780.x

[10] SAS (Statistical Analyses System Institute) (2002) SAS User’s Guide: Statistic. SAS Institute INC, Cary.

[11] Freitas, F.C.L., Ferreira, L.R., Ferreira, F.A., Santos, M.V., Agnes, E.L., Cardoso, A.A. and Jakelaitis, A. (2005) Formação de pastagem via consórcio de Brachiaria brizantha com o milho para silagem no sistema de plantio direto. Planta Daninha, 23, 49-58. http://dx.doi.org/10.1590/S0100-83582005000100007

[12] Jakelaitis, A., Daniel, T.A.D., Alexandrino, E., Simões, L.P., Souza, K.V. and Ludtke, J. (2010) Maize and Forage Grass Cultivars under Monocropping and Intercropping Systems. Pesquisa Agropecuária Tropical, 40, 380-387. http://dx.doi.org/10.1590/S1983-40632010000400008

[13] Mar, G.D., Marchetti, M.E., Souza, L.C.F., Gonçalves, M.C. and Novelino, J.O. (2003) Out-of-Season Maize Yielding Potential as Affected by Nitrogen Doses and Ways of Application. Bragantia, 62, 267-274.

[14] Melo, W.M.C., Von Pinho, R.G., Carvalho, M.L.M. and Von Pinho, E.V.R. (1999) Evaluation of Cultivars of Corn for Silage Production in the Region of Lavras-MG. Revista Ciência e Agrotecnologia, 23, 31-39.

[15] Costa, H.J.U., Janusckiewicz, E.R., Oliveira, D.C., Melo, E.S. and Ruggieri, A.C. (2012) Forage Mass and Morphological Characteristics of Corn and Brachiaria brizantha cv. Piatã Cultivated in Consortium System. ARS Veterinária, 28, 134-143. http://www.arsveterinaria.org.br/index.php/ars/article/viewFile/397/443

[16] Farinelli, R., Penariol, F.G., Bordin, L., Coicev, L. and Fornasieri Filho, D. (2003) Agronomic Performance of Maize Cultivars in Normal and Late Season Crops. Bragantia, 62, 235-241.

[17] Pedreira, B.C., Pedreira, C.G.S. and Silva, S.C. (2009) Herbage Accumulation during Regrowth of Xaraés Palisadegrass Submitted to Rotational Stocking Strategies. Revista Brasileira de Zootecnia, 38, 618-625. http://dx.doi.org/10.1590/S1516-35982009000400005

[18] Lara, M.A.S. and Pedreira, C.G.S. (2011) Potential Carbon Assimilation Estimate in Canopies of Brachiaria Species. Pesquisa Agropecuária Brasileira, 46, 743-750. http://dx.doi.org/10.1590/S0100-204X2011000700010

[19] Maia, G.A., Costa, K.A.P., Severiano, E.C., Epifanio, P.S., Flávio Neto, J., Ribeiro, M.G., Fernandes, P.B., Silva, 
J.F.G. and Gonçalves, W.G. (2014) Yield and Chemical Composition of Brachiaria Forage Grasses in the Offseason after Corn Harvest. American Journal of Plant Sciences, 5, 933-941. http://dx.doi.org/10.4236/ajps.2014.57106

[20] Lemaire, G. (2001) Ecophysiology of Grasslands: Dynamic Aspects of Forage Plant Populations in Grazed Swards. Gomide, J.A., Mattos, W.R.S. and Silva, S.C., Eds., International Grassland Congress, 19, Fealq, São Pedro, 29-37.

[21] Galzerano, L., Malheiros, E.B., Raposo, E., Morgado, E.S. and Ruggieri, A.C. (2013) Accumulation and Disappearance of Forage and Changes in the Pasture Structure of Xaraes Palisadegrass Subjected to Grazing Intensities and Intermittent Stocking. Semina: Ciências Agrárias, 34, 2485-2496. http://dx.doi.org/10.5433/1679-0359.2013v34n5p2485

[22] Nantes, N.N., Euclides, V.P.B., Montagner, D.B., Lempp, B., Barbosa, R.A. and Gois, P.O. (2013) Animal Performance and Sward Characteristics of Piata Palisade Grass Pastures Subjected to Different Grazing Intensities. Pesquisa Agropecuária Brasileira, 48, 114-121. http://dx.doi.org/10.1590/S0100-204X2013000100015

[23] Sbrissia, A.F. and Silva, S.C. (2008) Comparison of Three Methods for Estimating Leaf Area Index of Marandu Palisadegrass Swards under Continuous Stocking. Revista Brasileira de Zootecnia, 37, 212-220. http://dx.doi.org/10.1590/S1516-35982008000200006

[24] Sousa, B.M.L., Santos, M.E.R., Vilela, H.H., Silveira, M.C.T., Rocha, G.O., Freitas, C.A.S., Silva, N.A.M. and Nascimento Júnior, D. (2013) Piata Palisade Grass Deferred with Two Distinct Initial Heights: Luminous Environment and Tillering Dynamics. Revista Brasileira de Zootecnia, 42, 36-43. http://dx.doi.org/10.1590/S1516-35982013000100006

[25] Fernandes, L.O., Reis, R.A., Paes, J.M.V., Teixeira, R.M.A., Queiroz, D.S. and PaschoaL, J.J. (2015) Performance of Gir Young Bull Maintained in "Brachiaria brizantha” Pastures Submitted to Different Management. Revista Brasileira de Saúde e Produção Animal, 16, 36-46. http://revistas.ufba.br/index.php/rbspa/article/download/3158/1643

[26] Euclides, V.P.B., Macedo, M.C.M., Valle, C.B., Barbosa, R.A. and Gonçalves, W.V. (2008) Forage Yield and Sward Structure Characteristics of Brachiaria brizantha Cultivars under Grazing. Pesquisa Agropecuária Brasileira, 43, 1805-1812. http://dx.doi.org/10.1590/S0100-204X2008001200023

[27] Pinho Costa, K.A., Severiano, E.C., Simon, G.A., Epifanio, P.S., Silva, A.G., Costa, R.R.G.F., Santos, C.B. and Rodrigues, C.R. (2014) Nutritional Characteristics of Brachiaria brizantha Cultivars Subjected to Different Intensities Cutting. American Journal of Plant Sciences, 5, 1961-1972. http://dx.doi.org/10.4236/ajps.2014.513210 